\title{
A Study on Equivalence in the Indonesian-English Translation of Ismail's Selected Poems
}

\author{
Faradila Oktaviani \& Sigfrieda A.S. Mursinta Putri \\ faraokt@gmail.com \& siegfrieda@ukrida.ac.id \\ Faculty of Humanities and Social Sciences, Universitas Kristen Krida Wacana
}

\begin{abstract}
This study aimed to find out the translation procedures used by translator and the equivalence applied in the translation result of the poem. This study applied translation procedure theory from Vinay and Dalbernet (1995) and equivalence theory from Nida and Taber (1974). The data was taken from Ismail's poems and the translated version by McGlynn. Each line of the poem was analyzed in order to find the category of translation procedures used and equivalence which focused on the meaning in the translation result. Some suggestions were also given when this study found some inappropriate translations. This study used qualitative method and primary research. The analysis result showed that the translator used some translation procedures while translating. There were single procedures used, such as literal translation, transposition, modulation, equivalence and adaptation. There were also multiple procedures used, such as modulation and reduction, transposition and modulation, transposition and expansion, literal translation and reduction, and literal translation and expansion. The most translation procedure used was literal translation. There were also found formal equivalence and dynamic equivalence in the translation result. The most equivalence used was dynamic equivalence.
\end{abstract}

Keywords: poem, translation procedure, equivalence

\section{Introduction}

Language is an important thing to do a communication; people can also share their ideas, opinions and emotions using language. Translation is an activity that is related into written language. Translation does not only cover news, articles, novels, stories, but also other literary works such as poems and songs. Poem is a unique literary work. It is usually written figuratively. Translating a poem is a quite difficult to do, the meaning and the feeling of the translated poem should be transferred well in order to keep the aesthetic form of the original poem (Hassan, 2011). Due to this reason, translating a poem needs the right and appropriate method in order to keep the equivalent result when people read the original poem and the translated one. To achieve a good translation, translators have to know the translation procedures. Translation procedure is steps or ways to follow before translating SL to TL (Nida, 1964). It is important for translators because it helps them translate better and know how to convey the idea and message from SL into TL. Not only the translation procedure that should be considered, but also the equivalence of SL to TL is needed. Therefore, this study aims to know the translation procedures used by translator and the equivalence applied. This study can show how the translator translates a poem and its translation still conveys the message that the author wants to convey to the readers, give more explanation and description about translation procedures and equivalence, and become a reference to a further research.

This study analyzes Indonesian poem and the translated version in English. This 
study uses translation procedure theory from Vinay and Dalbernet (1995) and equivalence theory from Nida and Taber (1974). This study focuses on the equivalence in the meaning. Vinay and Dalbernet (1995) state that there are seven translation procedures which are borrowing, calque, literal translation, transposition, modulation, equivalence and adaptation. The theory of equivalence from Nida and Taber (1974) divides equivalence into two types which are formal equivalence and dynamic equivalence. Formal equivalence is transferring the meaning of source language into target language without adding the translators' ideas and thoughts. This is more focused on word for word translation. Dynamic equivalence is transferring the meaning of the source language into target language that convey the same meaning but does not use the exact phrase or idiom of the SL. This is more focused on thought-forthought than word-for-word.

\section{Methods}

This study was qualitative method which was a way to describe and explain things as if it was. This study was also a primary research. The data was taken from poems Pantun Terang Bulan di Midwest and Adakah Suara Cemara by Ismail. Each line in the translation result of Pantun Terang Bulan di Midwest and Adakah Suara Cemara were put in data analysis to find out the translation procedure applied. The data would be analyzed based on the theory of Vinay and Dalbernet (1995). They would be categorized into one or more translation procedure. After analyzing the translation procedure, this study also analyzed the equivalence applied in the target language. The data would be analyzed using theory of equivalence from Nida and Taber (1974).

\section{Translation Procedure Analysis}

This study found there were some procedures used by the translator. It was divided into two categories, they were single procedure and multiple procedure. The single procedure means that the translator only uses one procedure while translating the poem such as literal translation, transposition, modulation, equivalence and adaptation.
Multiple procedure means that the translator uses more than one procedure while translating the poem such as modulation and reduction, transposition and modulation, transposition and expansion, literal translation and reduction and literal translation and expansion.

\section{Single Procedure}

Here are some single translation procedures found in this study. First, the translator used literal translation procedure.

\section{(1) SL: Sebuah bulan sempurna TL: A perfect moon}

Echols and Shadily state that the word bulan is translated into "1) month, 2) moon" (2014, p. 105). The word sempurna is translated into "1) perfect, 2) complete, 3) be given a proper ceremony" (2014, p. 563). From the example above, translator used literal translation procedure where translator translates it word by word but still based on grammatical structure in the target language.

The second translation procedure was transposition. Here is the example.

\section{(2) SL: Adakah melintas sepintas}

TL: Is it the fleeting passage

In this line, the translator was translating adakah melintas sepintas into "is it the fleeting passage". The translator used transposition while translating this line, the word melintas as a verb was translated into "passage" as noun and the word sepintas as a noun was translated into "fleeting" as an adjective.

The third translation procedure was modulation.

(3) SL: Lingkarannya di sana

TL: An aureole around it

The phrase lingkarannya di sana was translated into an aureole around it. Echols and Shadily state that the word lingkaran is translated into "1) circle, 2) coil, 3) area, 4) surroundings" (2014, p. 390). According to Hornby (2015, p. 82), the word aureole means 
"a circle of light". The word di sana in the source language was translated into "around it". Based on Echols and Shadily, the word di sana is translated into "there" (2014, p. 540). The translator used modulation. The type of modulation is from abstract to concrete.

The fourth translation procedure was equivalence.

\section{(4) SL: Amat gemuruh}

\section{TL: Roll like thunder}

The translator translated the phrase amat gemuruh into "roll like thunder". The translator used the connector word such as "like" which can be qualified as simile. Based on Hornby (2015, p.138) simile means "a word or phrase that compares something to something else, using the words like or as". In this case, the translator uses equivalence procedure.

The fifth translation procedure was adaptation.

(5) SL: Lereng pohon pina

TL: The hillside pines

In KBBI, pina means "spreading bush plant, it is also known as Pterococcus corniculatus". Pina or Pterococcus corniculatus only lives in Southeast Asia (Zeven \& Wet, 1975). The translator translated it into "pines" in the target language. According to Hornby (2015, p. 1109), pines means "an evergreen coniferous tree that has clusters of long needle-shaped leaves". In this case, the translator used adaptation to translate this line.

\section{Multiple Procedures}

There were also some multiple translation procedures found in this study. Here are some examples. First, the translator used modulation and reduction procedure.

\section{(6) SL: Pantun Terang Bulan di Midwest}

TL: Full Moon in the Midwest

The phrase terang bulan in the source language was translated into "full moon" in the target language while according to Echols and Shadily terang bulan is "moonlight" (2014, p. 644). In this phrase, the translator used modulation which was abstract for concrete type. In this case, the translator also used reduction. The word pantun in the source language was not translated into target language. According to Newmark (1988), reduction is the process of omitting the element in the translation.

The second translation procedure found was transposition and expansion procedure.

\section{(7) SL: Bukit membisu}

TL: Hills lie mute

In this case, the translator used transposition which was the word membisu in the target language as a verb was translated into "mute" in the target language as an adjective. The translator also added the word lie in the target language. This procedure is known as expansion. According to Newmark (1988), expansion is the process of adding the element in the translation.

The third translation procedure was transposition and modulation procedure.

\section{(8) SL: Asap yang hancur}

TL: Smoke transforms

In this line, the translator used transposition. The phrase yang hancur here is an adjective while the translator translated it into "transforms" which is a verb. The translator also used modulation which was cause for effect. The phrase yang hancur was translated into "transforms" while according to Echols and Shadily, the word hancur is translated into "1) shattered, smashed, 2) dissolved" (2014, p. 231). This line is still connected to the next line, the translator wanted to inform the reader that the smoke has changed into grayish blue. Hornby (2015, p.1607) states that the word "transform" means "make a marked change in the form, nature, or appearance of". 
Therefore, the translator used the word "transforms".

The fourth translation procedure found was literal translation and expansion procedure.

(9) SL: Biru abu-abu

TL: To grayish blue

There was an addition of the word to in the target language, while in the source language there was no word ke. The translator still translated it literally. Echols and Shadily state that the word biru is translated into "blue" (2014, p. 93). The word abu-abu is translated into "gray" (2014, p. 2). So, the translator translated it into "grayish blue". In this line translator used literal translation procedure.

The fifth translation procedure was literal translation and reduction procedure.

\section{(10) SL: Gemersik daunan lepas}

\section{TL: Of rustling leaves}

The word gemersik in the source language was translated into "rustling" in the target language. Echols and Shadily states that the word gemersik is translated into "sound of rustling (of leaves)" (2014, p. 206). The word daunan is translated into "leaves" (2014, p. 150). In this case, the translator still used literal translation although the word lepas was not translated into target language and there was also an additional word "of" which was still connected with the previous line.

\section{Equivalence Analysis}

This study found that the translator used formal and dynamic equivalence. Formal equivalence means the translator transfers the meaning of source language into target language without adding the translators' ideas and thoughts. Dynamic equivalence means the translator transfers the meaning of the source language into target language that convey the same meaning but does not use the exact phrase or idiom of the SL. This study divided then based on part of speech. Here are the results of equivalence analysis.

\section{Nouns}

(11) SL: Seribu burung belibis

TL: A thousand of ducks

In this line, the translator translated burung belibis (noun) into "duck" (noun). It is also known as "whistling ducks". This species inhabits all manner of watercourses throughout its range, including lagoons, swamps, mangroves, rice fields, and palm savannas (Schwab \& Suomala, 2004). The translator only translated it into "duck" because this species indeed lives on the lake, so the reader of the target language automatically knows what the author meant. Actually, if the translator translated it into ducks, it would be too general because if people find out the word duck in the dictionary, the meaning is bebek. According to Charles (2012), the characteristics of whistling duck are similar with the other species of duck which have long neck and slower flight. Therefore, the translator still conveyed the same meaning. Although the translator transferred the same part of speech but the translator used different word choice. This data is qualified as dynamic equivalence.

\section{Verbs}

\section{(12) SL: Bersinar agak merah}

TL: $\underline{\text { Sheds rosy light }}$

The translator translated the phrase bersinar agak merah into sheds rosy light. The word bersinar is a verb and translated into "sheds" as a verb too. The translator did not translate it literally. If the phrase is translated literally, it will be "shine rosy". The translator used "sheds rosy light" instead of "shine rosy" because shine rosy is incomplete, we cannot find out what rosy defines and usually rosy modifies a noun. So, this data is qualified as dynamic equivalence because the translator did not use the 
exact phrase but still conveyed the same meaning from source language into target language.

\section{Other Content Words}

(13) SL: Lebar dan keruh

TL: Wide and muddy

In this line, the translator also translated the phrase literally. The translator followed the dictionary while translating this text. The word lebar as an adjective was translated into "wide" as an adjective, the word dan as a conjunction was translated into "and" as a conjunction, and the word keruh as an adjective was translated into "muddy" as an adjective. Regarding the result of equivalence, this data is qualified as formal equivalence because the translator translated it literally and the structure of the source language is also preserved in the target language. There is nothing changed. From the way that the translator translated this line, it can be understood that the translator was consistent.

\section{Other Word Class}

(14) SL: $\underline{\text { buat Ati }}$

\section{TL: for Ati}

This line is qualified as formal equivalence. The phrase buat Ati is a prepositional phrase which was translated into "for Ati" as a prepositional phrase too. In this case, the translator translated it literally. The translator did not add or omit the word in the source language when he transferred it into target language. The translator also did not change the existing structure in the source language.

\section{The Implication of Translation Procedure and Equivalence Analysis}

Translation procedure is divided into two categories which are single procedure and multiple procedure. The result of this study means there are common procedures used in translating poem, such as literal translation, transposition, modulation, equivalence, adaptation, reduction and expansion. The most translation procedure used in this study is literal translation. The findings are different from the study by Abdullah (2014). The most procedure used in Abdullah study was modulation. In this study, the translator conveys the idea as close as possible with the original poem. The difference between the commonly used procedure in Abdullah's study and this study is caused by the difference in the way the poems are delivered. In Abdullah's study, the author of the poem delivered the message by putting it between the line. While in this study, the author of the poem was directly delivering the meaning with a little use of figurative language. It implies that the poem which used much figurative language tends to use modulation procedure. Meanwhile, the poem which does not use figurative language tends to use literal translation procedure.

Equivalence is divided into two types which are formal equivalence and dynamic equivalence. The most equivalence used is dynamic equivalence. The findings also conform the study by Fandi (2014). He analyzed the meaning equivalence in the subtitle of animated movie "Monster University". He used the equivalence theory from Nida and Taber (1974) and the result of his findings were also dynamic equivalence as the most equivalence used. The translator in Fandi's study and in this study preferred to use dynamic equivalence rather than formal equivalence when they focused on the meaning. It means that dynamic equivalence is the most common type of equivalence in translating poem when the focus is on the meaning.

\section{Conclusion}

In this study, the translator maintains the idea and context of the source language although the word chosen is different. The translator translates each line with one or more than one translation procedures. There is single procedure used in the translation process such as literal translation, transposition, modulation, equivalence and adaptation. There is also multiple procedure 
used in the translation process such as modulation and reduction, transposition and modulation, transposition and expansion and literal translation and expansion. The most translation procedure used in this study is literal translation. There are formal equivalence and dynamic equivalence found in the translation result. The most equivalence used is dynamic equivalence. This study concludes that the translator uses dynamic equivalence because the translator does not want to remove the feeling or beauty of the text. If the translator only uses the word-forword translation, the translation result does not sound natural and can remove the aesthetic value of the poem. Overall, both equivalence still convey the same idea although in dynamic equivalence the form is different.

The limitation of this study is this study only focuses on the translation procedure and equivalence on the meaning in the target language. In translating poem, the translator needs to know the idea of the poem which is the source language that is going to be translated, the characteristic of the poem and the general understanding that differs from each person's perspective. For further researches that analyze poem, focus on the equivalence can be done since poem has some elements that needs to be considered, such as the effect, the rhyme, and also the figurative language.

\section{References}

Abdullah, Muhammad Ridwan Roji. Transposition and Modulation Analysis on the Translation of Prayer For Rain into Do'a Minta Hujan. Thesis. Jakarta: Universitas Islam Negeri, 2014.

Charles, Afiya. "Dendrocygna autumnalis (Black-bellied Whistling Duck)." The Online Guide to the Animals of Trinidad and Tobago, 2012.

Echols, John M. and Hassan Shadily. Kamus
Indonesia Inggris. $3^{\text {rd }}$ Edition. Jakarta: Gramedia Pustaka Utama, 2014.

Fandi, Donny. Translation Procedures and Meaning Equivalence in Subtitle of the Animated Movie "Monsters University". Thesis. Jakarta: Universitas Islam Negeri, 2014.

Hassan, Bahaa-eddin Abdulhassan. Literary Translation: Aspects of Pragmatic Meaning. Uniter Kingdom: Cambridge Scholars Publishing, 2011.

Hornby, A. S. Oxford Advanced Learner's Dictionary of Current English. (L. Hey \& S. Holloway, Eds.). 9th Edition. Oxford: Oxford University Press, 2015.

Newmark, Peter. A Textbook of Translation. New York: Prentice-Hall International, 1988.

Nida, Eugene A. Toward a Science of Translating: With Special Reference to Principles and Procedures Involved in Bible Translating. Leiden: Brill, 1964.

Nida, Eugene A. and Charles R. Taber. The Theory and Practice of Translation. $7^{\text {th }}$ Edition. Netherlands: E. J. Brill, Leiden, 1974.

Schwab,Donald J. and Mark Suomala. "West Indian Whistling-Duck (Dendrocygna arborea) at the Great Dismal Swamp National Wildlife Refuge, Virginia." North American Birds, 2004. pp. 164-167.

Vinay, Jean Paul and Jean Darbelnet. Comparative Stylistics of French and English: In A methodology for translation. $11^{\text {th }}$ Edition. Philadelphia: John Benjamins, 1995.

Zeven A.C and J. M. J de Wet. Dictionary of cultivated plants and their regions of diversity. $2^{\text {nd }}$ Edition. Wageningen: Centre for Agricultural Publishing and Documentation, 1975. 